\title{
Effect of Product Image of SME in East Java Province on Purchasing Decisions
}

\author{
Darwin Yuwono Riyanto $^{1 *}$ Yosef Richo Adrianto $^{1}$ \\ ${ }^{1}$ Universitas Dinamika, Indonesia \\ *Corresponding author. Email: darwin@dinamika.ac.id
}

\begin{abstract}
This research was conducted with the intention to identify the effect of product image excellence, product image strength and product image uniqueness on the decision making of purchasing SME products in management study program students in East Java. The population determined in this study were all active students of management study programs in East Java Province. The sampling technique used in this study was purposive sampling. This research was conducted through a survey approach. The data in this study were analyzed using multiple regression techniques to test the hypothesis proposed in this study. This research has urgency both for the development of marketing science or for stakeholders related to the development of SMEs. The novelty element of this research compared to other studies in the same field is the use of dimensions in the product image that are excellence, strength and uniqueness that are enhanced into research variables. This research has proven that product image, product image strength and product image uniqueness have a significant influence on purchasing decisions.
\end{abstract}

Keywords: The Uniqueness of the Product Image; The Strength of the Product Image; Superiority of the Product Image; The Purchasing Decision.

\section{INTRODUCTION}

Purchasing decisions are determined by factors including other prices, packaging and the product itself. Purchasing decisions consider things that are very important for the company or consumers because of considerations regarding the decision to buy or not[1]. In this case, which is a major factor in product purchase decision making. Product valuation as a key to purchasing. In this discussion, the products agreed on the benefits incurred from the costs incurred by consumers to obtain. If the product has greater benefits compared to the costs incurred, of course consumers are interested inbuying.

The purchase decision process does not only end in the purchase transaction, but ultimately in the consumer purchase decision[2]. Post-purchase is a determinant for repurchasing. When consumers feel satisfaction with purchases made, the consumer's decision to make a repeat purchase will be taken. This is because the decision to purchase arises from the motivation within the consumer[3]. The motivation is certainly different for each consumer, so the company must be able to reach and maintain their respective market share so as not to turn tocompetitors[4].
One thing that can be done for this is brand image. The product is considered as a company's promise to consumers accurately in providing value and benefits for certain things. In addition, the product is understood as the value of a product both tangible and intangible in influencing market share. Therefore, the product plays a very important role because as a form of company promises to consumers. Thus it can be further understood that the product as a bond of consumer feelings to the company[5]. Every company can offer similar products, but not with the promises given. This is due to differences in views of existing products in consumers.

Therefore, every company is required to be able to create and offer highly quality products in order to be able to compete with competitors while maintaining the image of the product[6]. The purchase decision is also defined as a decision in buying a particular product. on the basis of perceptions of product attributes. The intended product attributes include quality, value and price. In this case it can be understood that consumers decide to buy not only on the basis of quality, but also in terms of costs[7]. Every company can do various waysto maintain or even improve product image[8]. The methods include 


\section{Procedia Business and Financial Technology}

Proceedings of the 2nd International Conference on Business and M anagement of T echnology (ICO N BM T 2020) - Part 2

utilizing technology, setting competitive prices. do promotions on target and others[9].

In addition, the purchase decision is also interpreted as a fulcrum that gives rise to a certain action. In purchasing, consumers' decision to buy depends on the motivation that exists in these consumers. In order to meet the needs and desires of consumers, companies must be able to understand appropriately related to consumer behavior[10]. Consumer behavior can be known through consumer attitudes. Consumer attitudes are accurate consumer responses to products. These responses can be positive or negative, agree or disagree. If the company is able to understand consumer attitudes towards the products offered, then the company can determine further strategies in maintaining or even improving product quality according to what is needed and desired by consumers[11].

In East Java, most students, especially in the study program of consumer behavior management, stems from attitudes, product humility and subjective norms[12]. Consumer behavior is most commonly found in fashion products produced by small and medium enterprises (SMEs). They argue that SME products are very good quality and have affordable prices. It is also influenced by attitude factors, namely on the basis of liking the reliability of SME products, so it is certain to have beneficial benefits for them[13]. Therefore, the factors that attract students in making purchasing decisions on SME fashion products need to be examined. Based on these explanations, research is needed on "The Effect of Product Image on Decision Making Purchases of SME Products in Management Study Program Students in East Java".

\section{LITERATURE REVIEW}

\subsection{Product Image}

Product image is defined as a set of consumer perceptions of the product. This perception depends on the experience and information obtained by consumers. The image formed from this perception impacts purchasing decisions and ends in product loyalty. Product image includes two aspects, namely cognitive aspects and affective aspects[9]. Cognitive aspects are consumers' knowing and feeling that the product is able to meet the needs and desires of consumers, while the affective aspect is the emotional sense of consumers that the product is able to provide pleasure, comfort andothers.

Product image is also understood as a consumer's preference for products that start from the entire product display in the minds of consumers[6]. The product display consists of product performance display and product image display, which is in accordance with the attributes and advantages of the product. In addition, the product image is also defined as a series of product perceptions that are formed from past consumer experiences in using or consuming the product.

Product image depends on the sense of confidence and experience of the product. Therefore, consumers who have a positive image about the product are certainly interested in making a purchase[14]. The product image consists of three elements including the attributes, benefits and personality of the product. Product attributes are all things related to the product such as content, price, taste and product packaging.

Product benefits are the benefits obtained by consumers for the use or use of the product. Product personality is a characteristic or product characteristic. Product images are formed by sharing factors. The factors that shape the image of the product include excellence, strength and uniqueness of the product. Thus it can be concluded that the product image is the perception and preference of the product derived from the appearance of the product in the minds ofconsumers.

\subsection{Buying Decision}

Purchase decisions occur between two or more parties. In general, the party consists of five people. First, the initiator is the party who first recommends buying a product. Second, the influence giver is the party who has the strongest perception in the final purchase decision process. Third, the decision maker is the party that determines the product purchase. Fourth, the buyer is the person who makes the purchase. Fifth, users are people who use or consume products.

Companies, especially marketers, must be able to understand how the consumer decides to buy. In this case what must be understood is the party that makes the purchase decision and the stages of the purchasing process. This is because purchasing decisions vary by consumer. Moreover, if the purchase decision involves a variety of considerations and many.

Therefore, purchasing decisions dependon how marketers act and evaluate and consumer perceptions. Purchasing decisions consist of five stages: problem identification, information search, alternative assessment, purchase and post-purchase valuation[7]. The five stages can be used as a marketing strategy and communication by the marketer. In addition, purchasing decisions are also influenced byseveral other factors such as cultural, social, personal and psychological factors[15].

The cultural factors in question are social class, subculture and others. Social factors in question are family, consumer social status and others. Personal factors in question are lifestyle, economic conditions, personality, and self-concept of consumers. 


\section{Procedia Business and Financial Technology}

Proceedings of the 2nd International Conference on Business and M anagement of T echnology (ICO N BM T 2020) - Part 2

Psychological factors in question are motivation, perception, learning process, trust and consumer behavior[4]. Purchasing decisions are determined by various factors including price, packaging and the product itself[3]. Purchasing decisions are understood as very important for companies and consumers because they have an impact on whether to buy or not.

\subsection{The Relationship between Product Image and Purchasing Decision}

It has been explained that the product image is a set of consumer perceptions of the product. Therefore, if there is a change in the product, especially the brand, it will also affect the change in perception in the minds of consumers[5]. Products with a strong image can certainly excel in long-term competition. In addition, it can also attract, maintain and even increase consumer interest in buying[2]. Therefore, the stronger the product image, the higher the consumer's interest in buying. Thus, it can be concluded that the product image influences the purchase decision.

\subsection{Research Conceptual Framework}

Product image as the most important factor used by companies in attracting consumers to buy. This is because the product plays a very important role in purchasing decisions, so the purchasing decision depends on consumers' perceptions of the product through several factors such as cultural, social, personal and psychological factors. The better the consumer's perception of the product, the higher the consumer's interest in buying. In addition, consumer buying interest also depends on the comparison between price and product quality. This is because the price is used as a form of product quality. The higher the product price, the better the product quality. In this case, if the price of the product is high, but does not have good quality, consumers are not interested in buying it. Thus, research hypotheses can be as follows: H1A The uniqueness of the product image has a positive and significant effect on the decision to purchase SME products in EastJava.

H1B The strength of the product image has a positive and significant impact on the decision to purchase SME products in EastJava.

H1C The superiority of the product image has a positive and significant impact on purchasing decisions for SME products in East Java.

$\mathrm{H} 2$ The uniqueness of the product image, the strength of the product image and the superiority of the product image simultaneously have a positive and significant impact on purchasing decisions for SME products in EastJava.

\section{RESEARCH METHODS}

\subsection{Research Design}

This research was conducted with a survey approach. Survey research is research conducted by examining problems that occur along with sociological and psychological factors that exist both in large and small populations.

Based on the data obtained, this study is included in quantitative research. Quantitative research is research that analyzes hypotheses from problems that occur by providing answers according to data analysis obtained from respondents. The independent variables in this study consisted of three namely the uniqueness of the product image $(\mathrm{X} 1)$, the strength of the product image (X2) and the superiority of the product image (X3) with one dependent variable, the purchasing $\operatorname{decision}(\mathrm{Y})$.

\subsection{Population, Samples and Sampling Techniques}

The population determined in this study were active students of management study programs in various tertiary institutions in East Java Province in the academic year 2019/2020. The sample determined in this study was an active student in a management study program in East Java Province who had consumed or was limited to knowing the existence of SME products. Sampling of respondents in this study using purposive sampling technique. Purposive sampling technique is sampling that refers to certain characteristics in accordance with research needs. The characteristics determined are active students of management studies in East Java Province. Determination of the number of samples is based on the number of students of 200 people. However, only about $10-15 \%$ or $20-25 \%$ is taken. Based on location, this study prioritizes students in the Surabaya, Sidoarjo, Pasuruan and Probolinggo regions to achieve a better level of generalization of research results.

Data collection techniques used in this study were questionnaires. Questionnaire is a data collection technique by providing various written statements to respondents. The statement was made for the problems that were examined including the strength of the product image, the uniqueness of the product image, the uniqueness of the product and the willingness of consumers to buy. The questionnaire was given to respondents for three days to be answered by respondents, so researchers expect answers that are true and honest from respondents. In analyzing data, the techniques used are instrument test, classic assumption test and multiple regression analysis through the SPSS for windows program. 


\section{Procedia Business and Financial Technology}

Proceedings of the 2nd International Conference on Business and M anagement of T echnology (ICO N BM T 2020) - Part 2

\subsection{Test Instrument}

The instrument trials consisted of two namely validity and reliability tests. Validity test is used to find out how much the ability of statement items in explaining variables in order to obtain valid data. The quality of statement items in explaining variables depends on the amount of data available. Validity test is determined through the Correlated Item-Total Correlation value. The Correlated Item-Total Correlation value is compared with the $r$ table value.

The $r$ table value is obtained from table $r$ with the number of respondents and the level of significance determined (5\%). The formula for knowing the number of respondents is $(\mathrm{df})=\mathrm{n}-2$. Thus, if the value of Correlated Item-Total Correlation> $r$ table, the statement item is said to be valid. Reliability test is used to find out the magnitude of the respondent's answers on the statement items are reliable. Reliability in question is trustworthy. The reliability test is determined on the value of Cronbach's Alpha compared to the minimum value of Cronbach's Alpha (0.70). Thus, if the Cronbach's Alpha value $>0.70$, then the statement item is declared reliable.

\subsection{Hypothesis Testing}

Discriminant validity of the measurement model with reflexive indicators is assessed based on cross loading construct measurements. The model has good discriminant validity, if each loading value of each indicator of a latent variable has the greatest loading value with another loading value of other latent variables. Based on the table above, it can be seen that the value of crosss loading for each indicator of each latent variable is greater than the value of cross loading if it is associated with the latent variable. Thus, overall each latent variable estimated satisfies good discriminant validity.

Discriminant validity can also be seen from the average variance extracted (AVE) value. The minimum AVE to state that the reliability of the indicator has been achieved is greater or equal to 0.50 . Based on the test results on the reliability composite value in the above table, it can be concluded that all constructs meet the reliable criteria. This is indicated by all the composite reliability constructs having values above 0.60 .

Hypothesis testing is done to determine the relationship between research variables. The data used in testing this hypothesis is the value contained in the output result for inner weigth. In Partial Least Square (PLS) statistical testing, each hypothesized relationship is carried out using estimates. In this case the bootstrap method is performed on the sample.

\section{DISCUSSIONS}

In Partial Least Square-PLS testing statistically, each hypothesized relationship is carried out using estimates. In this case the bootstrap method is performed on the sample. Following, the test results with bootstrapping from PLS analysis. The relationship between product image uniqueness with a significant purchase decision with a T-statistic of $10.778>1.96$. The original sample value is positive that is equal to 0.672 which indicates that the direction of the relationship between product image uniqueness with the purchase decision is positive. The relationship between product image power and purchase decision is significant with a T-statistic of $6.688>1.96$.

The original sample value is positive that is equal to 0.484 which indicates that the direction of the relationship between product image power and purchase decision is positive. The relationship between product image advantage with purchase decision is significant with T-statistic of $9.772>1.96$. The original sample value is positive that is 0.212 which shows that the direction of the relationship between the product image advantage with the purchase decision is positive.

\section{CONCLUSION}

This research succeeded in proving that the product image uniqueness variable influences the purchase decision. In order to provoke purchase decisions on product offerings, SMEs should continue to improve product image uniqueness, especially on functional attributes. This research also proves that product image power influences purchase decision. SME is advised to be able to maintain and enhance the strengths in the offered product image. In addition, this study also proves that the product image advantage variable influences the purchase decision. This can be interpreted that the SME must be able to create while maintaining the advantages of the products offered.

This study also has a number of limitations and disadvantages although this research is able to uncover important findings related to purchase decisions in the perspective of product image. It is expected that future studies will be able to perfect this research. This research only focuses on assessing one type of industry, namely SME. This study is also limited to respondents who are consumers in East Java. The variables in this study are also limited to the product image variable, while many other variables can be examined as determinants of the purchase decision. This study also only uses SEM-PLS data analysis techniques with the help of SmartPLS while many 


\section{Procedia Business and Financial Technology}

Proceedings of the 2nd International Conference on Business and M anagement of T echnology (ICO N BM T 2020) - Part 2

other technical data analysts can be used.

Therefore, this study recommends further research so that the purchase decision study can be extended to other industrial sectors, broadens the type and domicile of respondents as unit analysis, develops or studies other variables as determinants of purchase decisions, and utilizes and adopts other data analysis techniques in accordance with the development research complexity.

\section{ACKNOWLEDGEMENT}

The researcher would like to thank the Ministry of Research and Technology of Higher Education who has funded this research in the grant scheme. The researcher also thanks the editors and reviewers for their valuable input and suggestions for the perfection of this paper. The researcher also thanks all those who support the activities in this study.

\section{REFERENCES}

[1] M. Pant, A. S. Virdi, and D. S. Chaubey, "Examining the Effect of Marketing Innovations on GPMA: A Study Using the PLS - SEM Approach," Glob. Bus. Rev., vol. 21, no. 3, pp. 1-12, 2018, doi: 10.1177/0972150918779160.

[2] R. Kumar and V. Tripathi, "Green Advertising : Examining the Role of Celebrity's Credibility Using SEM Approach," Glob. Bus. Rev., pp. 120, 2019, doi: 10.1177/0972150919862660.

[3] A. N. Kashi, "Exploring Consumer Purchase Behaviour: Foreign Versus Local Brands," Glob. Bus. Rev., vol. 14, no. 4, pp. 587-600, 2013, doi: 10.1177/0972150913501600.

[4] B. Jha, "The Role of Social Media Communication: Empirical Study of Online Purchase Intention of Financial Products," Glob. Bus. Rev., 2019, doi: 10.1177/0972150919848912.

[5] N. Udomkit, "The Analysis of Bangkok Coffee Chain's Consumers and the Influence of Brand Personalities on their Purchasing Decision," Glob. Bus. Rev., vol. 16, no. 3, pp. 415-424, 2015, doi: 10.1177/0972150915569929.
[6] A. Y. A. Fianto, "The Antecedents of Purchase Decision for Hijab Fashion Products," Manajemen, vol. 12, no. 1, pp. 154-165, 2020.

[7] A. Y. A. Fianto, "Satifaction As Intervening For The Antecedents Of Intention To Revisit: Marine Tourism Context In East Java," Relasi, vol. 16, no. 1, pp. 179-207, 2020.

[8] R. Santoso and A. Y. A. Fianto, "Pengaruh Marketing Mix Produk Jasa terhadap Keputusan Berkunjung Wisata Bahari Jawa Timur," Kinerja, vol. 17, no. 1, pp. 69-79, 2020.

[9] R. Santoso, R. Shinta, and A. Y. A. Fianto, "Pengaruh Bauran Pemasaran Jasa terhadap Keputusan Berkunjung ke Wisata Bahari Jawa Timur," Manaj. dan Bisnis, vol. 4, pp. 1-14, 2019.

[10] R. D. Pinasti, A. Y. A. Fianto, and W. Hidayat, "Penciptaan Buku Komik Sebagai Upaya Pengenalan Permainan Tradisional Kepada Remaja," Art Nouv., vol. 4, no. 1, 2015.

[11] E. Y. Ikawira and A. Y. A. Fianto, "Penciptaan Buku Ilustrasi Legenda Reog Sebagai Upaya Mengenalkan Budaya Lokal kepada AnakAnak," Art Nouv., vol. 3, no. 1, 2014.

[12] A. Jafar, A. Y. A. Fianto, and S. P. Yosep, "Penciptaan Buku Ilustrasi Permainan Tradisional Sebagai Upaya Pelestarian Warisan Budaya Lokal,” Art Nouv., vol. 3, no. 1, 2014.

[13] A. Marzuqi, "Penciptaan Motif Batik sebagai Ikon Kabupaten Lumajang," Institut Bisnis dan Informatika Stikom Surabaya, 2015.

[14] S. Lauwrentius, "Penciptaan City Brandingmelalui Maskot sebagai Upaya untuk Mempromosikan Kabupaten Lumajang,"

Unpublished Undergraduate Thesis, Visual Communication Design, 2015.

[15] R. Santoso, R. Shinta, and A. Y. A. Fianto, "Composing Marketing Mix for Better Destination Brand in Jawa Timur, Indonesia," Maj. Ekon., vol. XXIV, no. 1411, pp. 158-167, 2019.

.

